\title{
Status Analysis of Researches on Business Models Innovation in China
}

\author{
Shuyan LI \\ TSL School of Business \& Information Technology \\ Quanzhou Normal University \\ High Educational Engineering Research Center of \\ Fujian Province for E-Commerce Intelligent Based on \\ Cloud Computing and IOT \\ Quanzhou, China
}

\author{
Yuanren $\mathrm{WU}^{*}$ \\ TSL School of Business \& Information Technology \\ Quanzhou Normal University \\ High Educational Engineering Research Center of \\ Fujian Province for E-Commerce Intelligent Based on \\ Cloud Computing and IOT \\ Quanzhou, China \\ e-mail: yuanrenwu@126.com
}

\begin{abstract}
On the basis of the documentations on the innovation researches of business models in China included in CSSCI and the core journals of CNKI by using the software of CiteSpace, authors, institutions and journals of a large quantity of published papers on innovation researches of business models in China are sorted out systematically. In the meanwhile, by analyzing the high frequent used key words and their knowledge graphs, the status of innovation researches of business models in China is shown and serves as reference for future follow-up study for the scholars.
\end{abstract}

Keywords-innovation of business model; CiteSpace; knowledge graphs

\section{INTRODUCTION}

Innovation of business models has gained more and more attention from the business circles and academic world along with the rise of internet and emergence of E-commerce companies (Zott \& Amit, 2010) [1]. Afuah and other scholars believe that the innovation of business models refers to the collection of activities that a company realizes its own value by creating values for its customers [2]. Wang Xuedong and other scholars (2013) redefine the concept of innovation of business models and describes its characteristics by adopting the method of definition in the way of formal logic and comparison of concepts of innovation of business models in different subjects, which starts from the process and behavioral characteristics of innovation of business models [3]. The intensive study of innovation of business models will help in focusing on the leading status of current innovation of business models and providing experience reference for the corporate innovation of business models. Fruitful results on the innovation of business models have been achieved in the academic world of Chinese scholars [4] [5]. However, studies on the innovation of business models have been in a decentralized status and lack integrated and systematic analysis. There has been plenty of analysis on so many courses and fields through bibliometrics, such as quantitative economics (Wu Yuanren \& Shen Lisheng, 2015) [6] and open innovation (Li Shuyan \& Sun Rui, 2016) [7]. Therefore, the existing literatures are generally reviewed and summarized by the article, and research status is mastered in order to provide reference for disruptive innovation research. In order to compensate for this defect, this paper proceeds with a comprehensive and systematic integration and analysis on the documentations on the innovation research of business models in China, aiming to draw the outline of current innovation research of business models in China and serve as reference for future follow-up study for scholars.

\section{SOURCES AND Statistical ANALYsis OF DATA}

\section{A. Sources of Data}

Select to retrieve in CNKI of Journal Full-text Database. By typing "Innovation of Business Models" in the column of Topic, selecting "Economic and Management" in the column of Field of Study and selecting "Core Journal" and "CSSCI" in the column of Sources, a total of 960 pieces of paper (Date of Retrieval: January 2nd, 2017). A total of 895 pieces of paper were downloaded after eliminating the notice of Meeting, Call for papers and other unqualified essays.

\section{B. Statistics of Quantity of Published Papers}

See Chart 1 for the annual distribution status of the quantity of published papers on the innovation research of business models in China for 17 years. Essays were first published in 2000 and only a few essays on innovation of business models were published in 2006. Since 2007, researches on innovation of business models have gained more and more attention from the Chinese scholars and the quantity of published papers has been rising annually, which makes this topic a hotspot for study in the field of managerial economics. The trend to study innovation of business models remains strong.

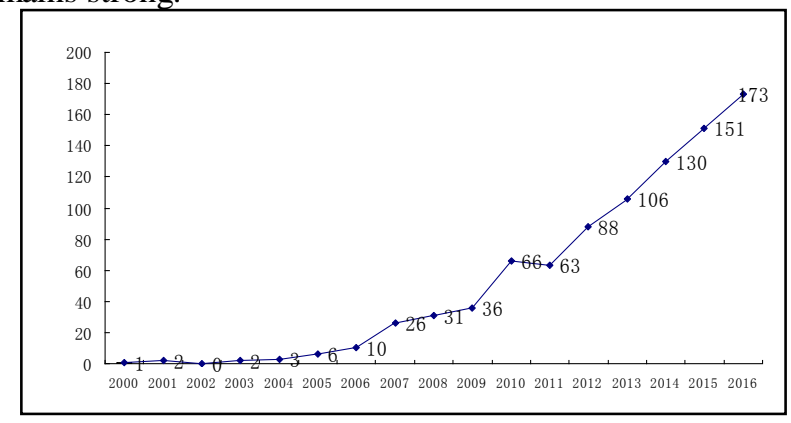

Figure 1. Quantity of documentations on innovation of business models in China 


\section{Analysis on the Authors Who Published a Large Quantity of Papers}

Counting in accordance with the quantity of published papers of at least 3 pieces of paper, see Table 1 for the distribution status of authors of frequent published papers on innovation of business models. A total of 42 authors who have published at least 3 essays on innovation of business models, including Wang Bingcheng of 8 essays, and Tong Yunhuan, Li Dong, Jing Hao, Dong Dahai and Jiang Jihai have also published comparatively more essays.

TABLE I. Authors Who PUblished a LARGE QUANTITY OF PAPERS ON INNOVATION OF BUSINESS MODELS

\begin{tabular}{|l|l|l|l|l|l|}
\hline Qty. & \multicolumn{1}{|c|}{ Author } & Qty. & \multicolumn{1}{|c|}{ Author } & Qty. & \multicolumn{1}{|c|}{ Author } \\
\hline 8 & $\begin{array}{l}\text { Wang } \\
\text { Bingcheng }\end{array}$ & 4 & $\begin{array}{l}\text { Hong } \\
\text { Zhisheng }\end{array}$ & 3 & Zhang Yuli \\
\hline 7 & $\begin{array}{l}\text { Tong } \\
\text { Yunhuan }\end{array}$ & 4 & $\begin{array}{l}\text { Xiang } \\
\text { Guopeng }\end{array}$ & 3 & $\begin{array}{l}\text { Hua } \\
\text { Hongbing }\end{array}$ \\
\hline 7 & Li Dong & 4 & Li Wei & 3 & $\begin{array}{l}\text { Chen } \\
\text { Guangren }\end{array}$ \\
\hline 6 & Jing Hao & 4 & Sun Rui & 3 & $\begin{array}{l}\text { Yue } \\
\text { Zhonggang }\end{array}$ \\
\hline 6 & Dong Dahai & 4 & Su Jingqin & 3 & Zhou Fei \\
\hline 6 & Jiang Jihai & 4 & Wang yanyu & 3 & Zhang Liping \\
\hline 5 & Chen Jin & 4 & Xie Wei & 3 & Xu Tianshu \\
\hline 5 & Feng Xuefei & 4 & Ji Huisheng & 3 & Chi Fengling \\
\hline 5 & Ding Hao & 4 & $\begin{array}{l}\text { Zhang } \\
\text { Zhengang }\end{array}$ & 3 & $\begin{array}{l}\text { Wang } \\
\text { Shengjin }\end{array}$ \\
\hline 5 & Yao Weifeng & 3 & Wei Jiang & 3 & Zhang Jian \\
\hline 5 & Xia Qinghua & 3 & Sun Yongbo & 3 & Li Xiang \\
\hline 5 & $\begin{array}{l}\text { Zhang } \\
\text { Xiaoling }\end{array}$ & 3 & Zeng Ping & 3 & Lu Tong \\
\hline 4 & Guo Yifu & 3 & Liu Yang & 3 & Chen Jixiang \\
\hline 4 & Yuan Lei & 3 & Li Changyun & 3 & Hu Baoliang \\
\hline & & & & \\
\hline
\end{tabular}

\section{Analysis on the Institutions that Publish a Large Quantity of Papers}

Counting in accordance with the frequency of published papers of at least 6 times, see Table 2 for the distribution status of 21 key institutions that publish papers on innovation research of business models. In the Graph, Tsinghua University School of Economics and Management has published the largest quantity of papers which reaches 23 pieces, followed by, Southeast University School of Economics and Management, South China University of Technology School of Business Administration and Renmin University of China School of Business, which have published at least 10 pieces of papers. Except the Industrial Economic Research Institution of Chinese Academy of Social Sciences, the other institutions among all the institutions that publish a large quantity of papers are university.
TABLE II. INSTITUTIONS THAT PUBLISH A LARGE QUANTITY OF PAPERS ON INNOVATION OF BUSINESS MODELS

\begin{tabular}{|c|c|c|c|}
\hline Qty. & Issuing Authorities & Qty. & Issuing Authorities \\
\hline 23 & $\begin{array}{l}\text { School of Economics } \\
\text { and Management, } \\
\text { Tsinghua University }\end{array}$ & 7 & $\begin{array}{l}\text { Institute of Industrial } \\
\text { Economy, Chinese } \\
\text { Academy of Social } \\
\text { Sciences }\end{array}$ \\
\hline 17 & $\begin{array}{l}\text { School of Economics } \\
\text { and Management, } \\
\text { Southeast University }\end{array}$ & 7 & $\begin{array}{c}\text { School of Business and } \\
\text { Administration, } \\
\text { Huaqiao University }\end{array}$ \\
\hline 14 & $\begin{array}{l}\text { School of Business } \\
\text { Administration, South } \\
\text { China University of } \\
\text { Technology }\end{array}$ & 7 & $\begin{array}{l}\text { School of Business } \\
\text { Administration, } \\
\text { Zhejiang Gongshang } \\
\text { University }\end{array}$ \\
\hline 10 & $\begin{array}{l}\text { School of Business, } \\
\text { Renmin University of } \\
\text { China }\end{array}$ & 6 & $\begin{array}{l}\text { School of Economics } \\
\text { and Management, } \\
\text { Tongji University }\end{array}$ \\
\hline 9 & $\begin{array}{c}\text { School of } \\
\text { Management, Zhejiang } \\
\text { University }\end{array}$ & 6 & $\begin{array}{l}\text { Beijing University of } \\
\text { Science and } \\
\text { Technology Dongling } \\
\text { School of Economics } \\
\text { and Management }\end{array}$ \\
\hline 8 & $\begin{array}{c}\text { Fudan University } \\
\text { School of Management }\end{array}$ & 6 & $\begin{array}{c}\text { Beijing Technology } \\
\text { and Business } \\
\text { University }\end{array}$ \\
\hline 8 & $\begin{array}{l}\text { School of Economics } \\
\text { and Management, } \\
\text { Wuhan University }\end{array}$ & 6 & $\begin{array}{c}\text { China Dalian Institute } \\
\text { of Advanced } \\
\text { Management }\end{array}$ \\
\hline 7 & $\begin{array}{l}\text { School of Economics } \\
\text { and Business } \\
\text { Administration, } \\
\text { Chongqing University }\end{array}$ & 6 & $\begin{array}{c}\text { Sun Yat - sen } \\
\text { University School of } \\
\text { Management }\end{array}$ \\
\hline 7 & $\begin{array}{l}\text { Antai College of } \\
\text { Economics and } \\
\text { Management, } \\
\text { Shanghai Jiaotong } \\
\text { University } \\
\end{array}$ & 6 & $\begin{array}{l}\text { Nankai University } \\
\text { Business School }\end{array}$ \\
\hline 7 & $\begin{array}{c}\text { Huazhong University } \\
\text { of Science and } \\
\text { Technology }\end{array}$ & 6 & $\begin{array}{l}\text { School of Economics } \\
\text { and Management, } \\
\text { Shenyang Aeronautics } \\
\text { and Astronautics } \\
\text { University }\end{array}$ \\
\hline 7 & $\begin{array}{c}\text { International Business } \\
\text { School, University of } \\
\text { International Business } \\
\text { and Economics } \\
\end{array}$ & & \\
\hline
\end{tabular}

\section{E. Analysis on Journals that Publish a Quantity of Papers}

Counting in accordance with the quantity of papers that at least 7 pieces of papers have been published, see Table 3 for the distribution status of 26 key journals that publish papers on innovation research of business models. In the Graph, Journals of Commercial Economics have published the largest quantity of papers of 121 pieces. Journal of Enterprise and Journal of Science \& Technology Progress and Policy follow by, with respectively 50 and 40 pieces of published papers. A total of 6 journals have published more than 20 essays, while there are 12 journals that have published papers with a quantity between 10 and 20 pieces. 
TABLE III. JOURNALS THAT PUblish a LARGE QUANTITY OF PAPERS ON INNOVATION OF BUSINESS MODELS

\begin{tabular}{|c|c|c|c|}
\hline Qty. & Issued Journal & Qty. & Issued Journal \\
\hline 121 & $\begin{array}{l}\text { Journal of Business } \\
\text { Economics }\end{array}$ & 12 & Business Studies \\
\hline 50 & Business management & 10 & Science of Science \\
\hline 44 & $\begin{array}{l}\text { Science \& Technology } \\
\text { Progress and Policy }\end{array}$ & 10 & China Soft Science \\
\hline 35 & $\begin{array}{l}\text { Science and } \\
\text { Technology } \\
\text { Management Research }\end{array}$ & 10 & $\begin{array}{l}\text { Journal of Beijing } \\
\text { Technology and Business } \\
\text { University (Social Science } \\
\text { Edition) }\end{array}$ \\
\hline 22 & $\begin{array}{ll}\text { China } & \text { Industrial } \\
\text { Economy } & \end{array}$ & 10 & $\begin{array}{l}\text { Modern } \\
\text { Science }\end{array}$ \\
\hline 20 & $\begin{array}{l}\text { China Science and } \\
\text { Technology Forum }\end{array}$ & 9 & Technical Economy \\
\hline 18 & Economic Management & 9 & $\begin{array}{ll}\text { Chinese Journal of } \\
\text { Management }\end{array}$ \\
\hline 17 & $\begin{array}{l}\text { Science of Science and } \\
\text { Management of S. \& T. }\end{array}$ & 9 & $\begin{array}{l}\text { China 's Circulation } \\
\text { Economy }\end{array}$ \\
\hline 15 & $\begin{array}{l}\text { Sales \& Marketing } \\
\text { (Management Edition) }\end{array}$ & 9 & $\begin{array}{l}\text { China Logistics \& } \\
\text { Purchasing }\end{array}$ \\
\hline 14 & $\begin{array}{ll}\text { Scientific } & \text { Research } \\
\text { Management } & \end{array}$ & 8 & $\begin{array}{l}\text { Management } \\
\text { modernization }\end{array}$ \\
\hline 13 & $\begin{array}{l}\text { Chinese } \\
\text { Theory }\end{array}$ & 8 & Management of the world \\
\hline 13 & $\begin{array}{l}\text { Science \& Technology } \\
\text { Progress and Policy }\end{array}$ & 8 & $\begin{array}{l}\text { Economic } \\
\text { Reference }\end{array}$ \\
\hline 12 & Enterprise Economy & 8 & Business Management \\
\hline
\end{tabular}

\section{ANALYSIS ON KeY WordS OF High FREQUENT USED} AND KNOWLEDGE GRAPHS

Key words are normally used for the authors to summarize the content of paper. High frequent used key words and their centrality of innovation research of business models are obtained by using the software of CitySpace. Counting in accordance with the frequency of key words that appear at least 6 times, 56 key words are found, which are listed in Table 3. As shown in Table 3, key words of innovation of business models, business models, innovation, technological innovation, strategic rising industry and Ecommerce rank the top 6, which indicates that the main study field of innovation research of business models is the strategic rising industry and the industry of E-commerce and that the research direction is closely related to the technological innovation. In the meanwhile, key words of Web of Things, Big Data, Internet Plus and Cloud Computing have also revealed that the innovation of business models also pays attention to relevant study of Internet.

The knowledge graphs of key words on innovation of business models have been shown in Chart 2 and each spot in the chart refers to corresponding key words. The more importance the function of centrality of the spot counts, the bigger the spot will be. The centrality of each key word means the bridge function of the spot to the other spots. The more importance the function of centrality of the spot counts, and it will have greater influence on the co-appearance of other key words in the paper. As shown in Chart 2, the centrality of key words of E-commerce, supply chain, technological innovation, core competence, Web of Things, case study, pattern of profits, intelligent manufacturing, business models, crowd funding and financial crisis have greater functional importance and they are the key points of innovation research of business models that are paid attention to by Chinese scholars.

TABLE IV. HIGH FREQUENT USED KEY WORDS ON INNOVATION RESEARCH OF BUSINESS MODELS

\begin{tabular}{|c|c|c|c|c|c|}
\hline Qty. & Key Words & Qty. & Key Words & Qty. & Key Words \\
\hline 341 & $\begin{array}{l}\text { innovation of } \\
\text { business } \\
\text { models }\end{array}$ & 9 & $\begin{array}{l}\text { Business } \\
\text { Performance }\end{array}$ & 7 & $\begin{array}{l}\text { management } \\
\text { accounting }\end{array}$ \\
\hline 225 & $\begin{array}{l}\text { business } \\
\text { models }\end{array}$ & 9 & Internet + & 7 & $\begin{array}{l}\text { technological } \\
\text { innovation }\end{array}$ \\
\hline 90 & innovation & 9 & $\begin{array}{l}\text { Model } \\
\text { innovation }\end{array}$ & 7 & $\begin{array}{l}\text { competition } \\
\text { among } \\
\text { enterprises }\end{array}$ \\
\hline 48 & $\begin{array}{l}\text { technological } \\
\text { innovation }\end{array}$ & 8 & $\begin{array}{l}\text { cloud } \\
\text { computing }\end{array}$ & 7 & $\begin{array}{l}\text { Management } \\
\text { innovation }\end{array}$ \\
\hline 29 & $\begin{array}{l}\text { strategic } \\
\text { rising } \\
\text { industry }\end{array}$ & 8 & $\begin{array}{l}\text { Open } \\
\text { Innovation }\end{array}$ & 7 & Development \\
\hline 22 & E-commerce & 8 & $\begin{array}{l}\text { Competitive } \\
\text { Advantage }\end{array}$ & 7 & $\begin{array}{l}\text { Industrial } \\
\text { upgrading }\end{array}$ \\
\hline 17 & Value Chain & 8 & $\begin{array}{l}\text { Innovation- } \\
\text { driven }\end{array}$ & 7 & $\begin{array}{l}\text { Service } \\
\text { industry }\end{array}$ \\
\hline 17 & $\begin{array}{l}\text { Internet of } \\
\text { things }\end{array}$ & 8 & $\begin{array}{l}\text { Emerging } \\
\text { industry }\end{array}$ & 7 & $\begin{array}{l}\text { Emerging } \\
\text { technology }\end{array}$ \\
\hline 16 & Big Data & 8 & $\begin{array}{c}\text { Core } \\
\text { competitiven } \\
\text { ess }\end{array}$ & 6 & profit model \\
\hline 15 & $\begin{array}{l}\text { Value } \\
\text { Creation }\end{array}$ & 8 & enterprise & 6 & $\begin{array}{c}\text { Innovative } \\
\text { ways }\end{array}$ \\
\hline 15 & Case study & 8 & $\begin{array}{c}\text { Small and } \\
\text { medium } \\
\text { enterprises }\end{array}$ & 6 & $\begin{array}{c}\text { Independent } \\
\text { innovation }\end{array}$ \\
\hline 14 & supply chain & 8 & $\begin{array}{c}\text { financial } \\
\text { crisis }\end{array}$ & 6 & $\begin{array}{c}\text { Value } \\
\text { network }\end{array}$ \\
\hline 14 & $\begin{array}{l}\text { Destructive } \\
\text { innovation }\end{array}$ & 8 & $\begin{array}{c}\text { Retail } \\
\text { Enterprises }\end{array}$ & 6 & $\begin{array}{c}\text { Value } \\
\text { innovation }\end{array}$ \\
\hline 11 & the Internet & 8 & $\begin{array}{l}\text { The Internet } \\
\text { Finance }\end{array}$ & 6 & tencent \\
\hline 10 & $\begin{array}{l}\text { Industrial } \\
\text { integration }\end{array}$ & 8 & $\begin{array}{l}\text { Transformati } \\
\text { on and } \\
\text { upgrading }\end{array}$ & 6 & $\begin{array}{c}\text { Value } \\
\text { proposition }\end{array}$ \\
\hline 10 & $\begin{array}{l}\text { Innovation } \\
\text { Path }\end{array}$ & 8 & $\begin{array}{c}\text { New business } \\
\text { model }\end{array}$ & 6 & $\begin{array}{c}\text { New energy } \\
\text { vehicles }\end{array}$ \\
\hline 9 & $\begin{array}{l}\text { Influencing } \\
\text { Factors }\end{array}$ & 8 & $\begin{array}{c}\text { Entrepreneuri } \\
\text { al spirit }\end{array}$ & 6 & New ventures \\
\hline 9 & $\begin{array}{l}\text { Culture } \\
\text { Industry }\end{array}$ & 7 & $\begin{array}{l}\text { industry } \\
\text { chain }\end{array}$ & 6 & $\begin{array}{l}\text { Customer } \\
\text { value }\end{array}$ \\
\hline 9 & $\begin{array}{l}\text { Grounded } \\
\text { Theory }\end{array}$ & 7 & path & & \\
\hline
\end{tabular}




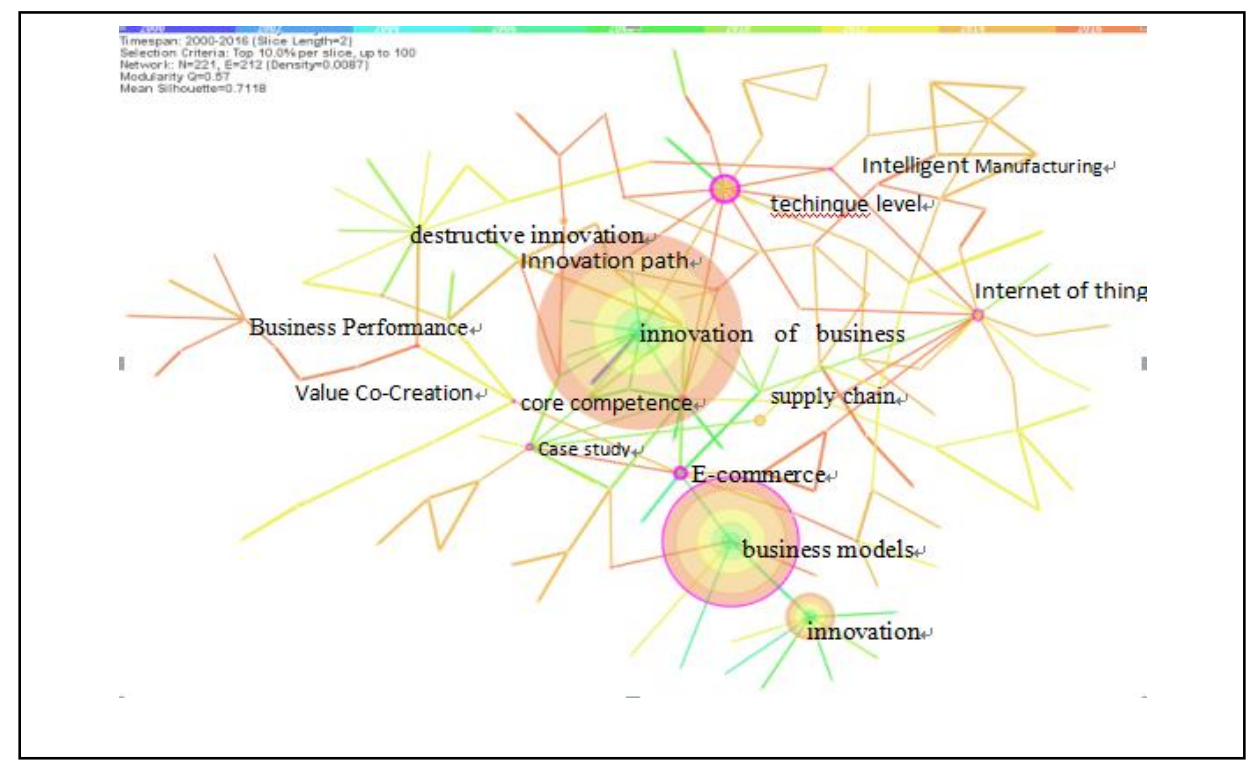

Figure 2. Knowledge graphs of key words of innovation research of business models

\section{CONCLUSION}

Bases on the data of 895 pieces of essays on innovation research of business models in China from CSSCI and the core journals of CNKI and with the help of the visualized software of CiteSpace, this paper has sorted out the authors, institutions and journals that publish a large amount of papers on innovation research of business models, and in the meantime, systematically sorted out the study status of this field by analyzing the high frequent used key words and their knowledge graphs. The research results have revealed that the quantity of published papers have been increasing annually and the trend of publication remains strong. Wang Bingcheng, Tong Yunhuan, Li Dong, Jing Hao and Dong Dahai are the authors who publish the largest quantity of papers on innovation research of business models. Among the institutions that publish papers of innovation research of business models, Tsinghua University School of Economics and Management has published the largest amount of papers, which is followed by Southeast University School of Economics and Management, South China University of Technology School of Business Administration and other institutions. Journals of Commercial Economics, Journal of Enterprise and Journal of Science \& Technology Progress and Policy are the journals that publish the largest amount of papers. By analyzing the high frequent used key words, it is found that innovation of business models, business models, innovations, technological innovation, strategic rising industry and E-commerce are the fields that catch the eye of scholars.

\section{ACKNOWLEDGMENT}

This research was financially supported by the Social Science Planning Project of Fujian Province "Research on mobile shopping repurchase intention based on the perspective of experience" (Grant NO. FJ2016B106). Corresponding author is Yuanren Wu. E-mail: yuanrenwu@126.com.

\section{REFERENCES}

[1] Zott C, Amit R, "Business model design: An activity system perspective,"Long range planning, vol.43,pp.216-226,2010.

[2] Afuah A, "Innovation management: Strategies, implementation and profits," Harward Business Review, vol.3/4,pp.73-84,2003.

[3] Wang X D, Dong D H, "Review and Prospect of Research on Business Model Innovation," Foreign economy and management, vol.35, pp.29-36,2013.

[4] Morris M, Schindehutte M, Allen J, "The entrepreneur's business model: Toward a unified perspective,"Journal of Business Research, vol.58, pp.726-735, 2005.

[5] Ye X Y, Sun R, Lin C P, "The Academic Groups and Categories of Foreign Business Model Innovation:Authors were citation analysis," Science of Science and Management of S. \& T.,Vol.11,pp. 8795,2014 .

[6] Wu Yuanren, Shen Lisheng, "A Study on Knowledge Map of Quantitative Economics in China: Bibliometric Analysis Based on CSSCI (2000-2014) ," Data Economic Dynamics,vol.8, pp.84-96, 2015.

[7] Li Shuyan, Sun Rui, "Analysis of Foreign Open Innovation Schools Based on the Author Co-citation Analysis," Science Research Management, vol.5, pp.10-18, 2016. 